\title{
PERSDELICTEN IN SURINAME
}

DOOR

\section{Ph. A. Samson (Paramaribo)}

In zijn werk Journalistiek leven in Curaçao heeft dr JoH. HARTOG een geschiedbeschrijving van de pers in Curaçao gegeven. Als aanhangsel van dit werk heeft de schrijver een en ander medegedeeld over de historie van de Surinaamse pers en bijeen verzameld hetgeen daaromtrent is gepubliceerd. Wij mogen de schrijver hiervoor dankbaar zijn.

Onder het hoofd „Het eerste persdelict 1796” lezen wij dat in 1796 tegen de Surinaamsche Spectator een klacht werd ingebracht en de uitgeefster strengelijk gewaarschuwd werd zich te onthouden van uitdrukkingen met de aangenomen principes van de openbare godsdienst in strijd.

De schrijver maakt geen onderscheid tussen persdelicten, waaronder wij willen verstaan vervolgingen ingesteld tegen redacteuren van nieuwsbladen met daarop gevolgde veroordelingen, en maatregelen, bestaande uit waarschuwingen en schorsingen, die tegen de pers in Suriname werden genomen.

In dit opstel willen wij een opsomming geven van veroordelingen uitgesproken ter zake van strafbare feiten door middel van de pers gepleegd, doch ons daarbij beperken tot vervolgingen ingesteld tegen de redactie van nieuwsbladen in Suriname. Welke preventieve maatregelen in de loop der tijden tegen de pers zijn genomen, zal in een volgend artikel worden behandeld.

HARTOG deelt mede dat de nieuwsbladen in het algemeen eerst laat critiek op plaatselijke toestanden geven en dat deze heden ten dage nog veelal zwak is in verband met de klein-plaatselijke toestanden (blz. 307).

Deze laatste toevoeging kunnen wij niet onderschrijven. Vaak is er scherpe, ja zelfs ruwe critiek, vooral op het beleid van Gouverneurs geleverd, al moet daarbij dadelijk worden toegegeven dat die critiek steeds van een bepaalde zijde kwam. 
Blijkens een hoofdartikel in Suriname van 19 Dec. 1899 (redacteur D. S. G. Morpurgo) was mr Willem van Emden, Kantonrechter en Lid van de Raad van Bestuur, de eerste opposant in de Surinaamse pers.

De redactie van het blad scheen niet veel op te hebben met deze magistraat, zijn afkeuring voor de verdere dienst in de tropen wordt onder het hoofd ,,een heuglijk nieuws" met ,onverdeeld genoegen" gemeld. Na de grieven tegen vaN EMDEN te hebben aangegeven zegt de redacteur: „Desniettemin is er iets, waarvoor rechtzinnigen en de niet tot de clique behoorende Kinderen van het Land mr Willem A. van Emden niet genoeg dankbaar zich kunnen betoonen: hij toch is de eerste, die ons en andere oppositie bladen is voorgegaan, en heeft geleerd dat de waarheid mag worden gesproken, en dat, tegen wien ook, mag worden gestreden voor het recht van anderen. De pittige, vaak scherpe en onbehouwen oppositie, welke hij èn in ons blad èn in Nederlandsche bladen gevoerd heeft tegen het Bestuur Jhr. vaN SYPESTEYN bracht in de journalistiek van Suriname een geheel anderen ommekeer, en schudde ons, doch vooral ook andere rechts- en overheidspersonen, die in latere dagen oppositie tegen volgende Besturen hebben gevoerd, vrij van den angst, die het algemeen beroerde om zijne gevoelens en meeningen ronduit te zeggen". De redactie eindigt met te schrijven dat zij later heeft ervaren dat de heftige oppositie van de heer van EMDEN niet was ter behartiging van het algemeen belang, maar wel en hoofdzakelijk om te kunnen botvieren de persoonlijke rancune, welke zijn familie niet tegen Gouverneur vAN SYPESTEYN, maar tegen de persoon van deze had.

Indien het juist is dat mr VAN EMDEN de eerste is geweest die felle critiek tegenover het Bestuursbeleid in Suriname heeft gevoerd, dan mag worden gezegd dat dit voorbeeld spoedig navolging heeft gevonden. De critiek tegenover J. H. A. W. baron van HeERdT tot Eversberg (1882-1885) 1) en zijn opvolgers Jhr mr M. A. DE Savornin Lohman (1889-1891) en mr W. Tonckens J.Lz. (1899-1902) 2) in Suriname was buitengewoon

1) De artikelen tegen het beleid en de persoon van deze Gouverneur werden, als gebundeldè overdrukken uit Suriname, in brochurevorm uitgegeven onder de titel Surinaamsche toestanden (Paramaribo, 1885). De schrijver is onbekend.

2) Op 23 Nov. 1889 weigerde het Hof van Justitie rechtsingang te verlenen tegen W. J. LABAD, redacteur van De West-Indiër, beklaagd van belediging van de wd. Gouverneur Tonckens, uit overweging

West-Indische Gids XXXII 
scherp en Jhr mr T. A. J. van Asch vaN WiJCK (1891-1896) nam in zijn op 9 Mei 1893 uitgesproken rede ter opening van de Staten stelling tegen een in het afgelopen jaar verrezen orgaan (Nieuwe Surinaamsche Courant), dat, gelijk hij zeide, zich ten taak stelde minachting voor het Bestuur en de gestelde machten op te wekken bij hen die in moeilijke omstandigheden verkeren.

Wie de Surinaamse couranten van de laatste helft van de 19de eeuw critisch doorleest, zal tot de conclusie moeten komen dat in talrijke gevallen een vervolging met succes zou zijn bekroond.

Het Bestuur van Gouverneur LoHMaN was een tijd van strijd en woeling; er heerste een scherpe strijd tussen Gouverneur en Volksvertegenwoordiging. Die strijd werd ook in de pers gevoerd. Terwijl in De Volksbode de daden van de Gouverneur geprezen werden, werd zijn beleid in Suriname en De West-Indiër scherp aangevallen en zeer onaangename critiek geleverd.

Het eerste persdelict dat wij in de Surinaamse kranten ontdekten betrof een vervolging ingesteld tegen F. W. Determan JR. auctionnair, 26 jaar, geboren te Amsterdam. Deze schreef in De West-Indiër van 27 en 30 November 1870 een artikel, ,Een Spaansche geschiedenis": een fantasie over een stad Equuwaja, in de provincie Parewuita, welk stadje liggende aan de linkeroever van een majestueuse stroom in een vruchtbare landstreek lag. Het volk van die stad en provincie was ontevreden over het flauwe bestuuur, el gobiernâdor wâs żwâk, onvererschillig, dann door deze, dan door gene invloed meegesleept, zonder enige waardigheid, bij het volk niet gezien, met gebrek aan praktische kennis, wankelmoedig en onzelfstandig, en zonder doortastendheid, alles op de lange baan schuivend, in het kort zonder enige eigenschap die in zijn betrekking iets waard is - en toch trok hij een aanzienlijk jaargeld.

Dit artikel werd beledigend geacht voor Gouverneur W. H. J. VAN IDSINGA (1867-1873). Beklaagde werd bij vonnis van het Hof van Justitie van 25 Februari 1871 veroordeeld tot gevangenisstraf van achttien maanden en de kosten van het geding wegens ,,het boosaardiglijk en in een gedrukt en verspreid geschrift, dus in het openbaar, beleedigen van den Gouverneur, 's Konings vertegenwoordiger in deze kolonie". Bij Gouvernementsresolutie van 6 Mei 1871, no. 746/2, werd aan de veroordeelde kwijtschelding verleend van zijn nog overige straftijd.

dat de geincrimineerde bestuurshandelingen niet in de tijd toen $\mathrm{mr}$ Tonckens wd. Gouverneur was, hadden plaats gehad en het artikel overigens voor diens persoon niet beledigend was. 
Tekenend voor de toestand in Suriname is de aanvang van het pleidooi van de verdediger mr A. C. Wesenhagen in deze zaak, zoals het in de locale bladen werd opgenomen. Spreker achtte het nodig om een opheldering te geven van zijn optreden, omdat hij om vele redenen niet beschouwd wilde worden sympathie te gevoelen voor roekeloze schrijverij en niet beschouwd wilde worden voorstander te zijn of zijn adhaesie te schenken aan de gemene, opgewonden toon waarop in de kolonie met aanranding van personen, bestuursdaden dikwijls worden gecritiseerd. Hij voegde eraan toe: „Het onbeschofte geschreeuw, de losbandige voorbarigheid, de grove personaliteiten, die bij sommige zich noemende journalisten in deze kolonie dikwijls voorzit, zie ik à regret hun weg vervolgen”. - , ,Niemand kan grooter afkeer hebben dan ik van den toon en de wijze van schrijven, die er nu en dan in sommige Surinaamsche dagbladen voorkomt, niemand kan meer dan ik dien schamperen, bespottelijk overmoedigen en belachelijk woesten toon afkeuren, waardoor zich helaas nu en dan die dagbladen meesterlijk, doch gelukkig ook schadeloos weten te onderscheiden".

Het tegen Determan gewezen vonnis werd in het Weekblad van het Recht van 24 April 1871, no. 33I4, gepubliceerd. De redactie tekende aan dat de drukpers in de kolonie onder zeer strenge wetten leeft, vooral als deze toepassing er van juist is, wat misschien mag betwijfeld worden.

In 1891 en 1892 werden vervolgingen ingesteld tegen redacteuren van De Volksbode, een blad dat het beleid van Gouverneur Jhr M. DE Savornin Lohman verdedigde. Nadat een der redacteuren tot f. 25 boete wegens hoon en tot 3 maanden gevangenisstraf en f. 100 boete wegens laster was veroordeeld, werden vier redacteuren van het blad vervolgd in verband met de Mei-woelingen in 1891. Een der redacteuren werd vrijgesproken, de overige schuldig verklaard aan , het te zamen en in vereeniging door gedrukte geschriften in het openbaar verspreid opruien van de menigte tot het plegen van wederspannigheid door gewelddadigen en feitelijken weerstand tegen ondergeschikte beambten der rechterlijke politie, handelende ter uitvoering van de bevelen van het, openbaar gezag, gepleegd door meer dan twintig gewapende personen tot vernieling van roerende zaken, begaan met openbaar geweld door een bende". Deze redacteuren werden veroordeeld tot gevangenisstraffen van drie jaar, een jaar en zes maanden en zes maanden.

Of door deze veroordeling bij de redacteuren der Surinaamse 
nieuwsbladen de schrik erin gebracht is of het Parket niet gemakkelijk tot vervolging overging weten wij niet, doch het duurt tot 1908 voor er weer een vervolging wordt ingesteld. In dat jaar schreef de pater-redacteur van De Surinamer in het nummer van 10 Dec. een artikel, ,De overname des beheers van twee plantages door het Gouvernement", waarin aan beheerders van plantages werd ten laste gelegd, dat zij gelden tot een bepaald doel verstrekt voor een ander doel hebben gebezigd.

Het verweer van de vervolgde bij de Rechter-Commissaris ter openbare zitting liet hij verstek gaan - dat hij geenszins het doel heeft gehad om te beledigen, werd door het Hof verworpen en bij vonnis van het Hof van Justitie van 20 Maart 1909 werd hij ter zake van laster, door in een gedrukt geschrift dat is openbaar gemaakt door verspreiding, aan iemand met het oogmerk om te beledigen feiten ten laste te leggen, welke, zo deze bestonden, degene wie zij zijn ten laste gelegd zouden blootstellen aan de verachting of de haat der ingezetenen, veroordeeld tot een geldboete van f. 100 subsidiair 7 dagen gevangenisstraf en de kosten van het geding ad f. 41.95. Een der overwegingen van het Hof was dat er voldoende grond bestaat om aan te nemen dat beklaagde tot zijn handelingen is gekomen door overmatig vertrouwen op verkregen inlichtingen.

Reeds het volgende jaar werd de redacteur van Suriname vervolgd wegens het schrijven van een artikel, ,"Kaf", waarín hij een commies-landmeter beledigde door o.m. te schrijven dat deze is bedreigd de laan te worden uitgezonden. De gevraagde rechtsingang wegens laster werd door het Hof geweigerd en de redacteur werd door de Kantonrechter bij vonnis van 28 April 1909 veroordeeld wegens belediging in geschrifte tot een geldboete van f. 5 subsidiair 2 dagen gevangenisstraf.

Naar aanleiding van een artikel over het gevelde vonnis werd dezelfde redacteur voor de rechter gebracht, doch vrijgesproken.

In 1913 kon het Surinaamse publiek weer smullen van ,een persdelict": De toenmalige redacteur van het nieuwsblad $D e$ West besprak en beoordeelde de bestuursdaden van de Gouverneur W. H. D. Baron van AsBeck en schreef: ,Waarlijk het wordt tijd dat de oogen van het moederland open gaan”. „Men moet daar begrijpen dat de Gouverneurszetel van Suriname te goed is om te dienen als middel om mensch $\bullet$ kwijt te raken, met wie men in Nederland om de een of ander reden zit opgescheept". „Het klinkt ruw om dit te zeggen, maar het belang van Moeder- 
land en kolonie eischt dat voor alles gezorgd wordt voor een eerlijk en bekwaam bestuur".

Nadat een poging van de redacteur-beklaagde om de leden van het Hof te wraken mislukt was, werd de zaak behandeld. Het door beklaagde als motief voor zijn handeling aangevoerde dat hij in het algemeen belang gehandeld heeft, werd verworpen, omdat naar het oordeel van het Hof het algemeen belang niet gediend wordt door het uitoefenen van critiek in nodeloos krenkende vorm. Het Hof overwoog verder dat beklaagde klaarblijkelijk gehandeld heeft in grote opgewondenheid over feiten en omstandigheden die, eenzijdig als hij was ingelicht, op hem de indruk hebben moeten maken van willekeur en onrecht en het bovendien de eerste maal is dat hij voor een dergelijk feit terecht staat en veroordeelde hem bij vonnis van 8 November 1913 wegens ,, het boosaardelijk en in een gedrukt en verspreid geschrift, dus in het openbaar, beleedigen van de vertegenwoordiger der Koningin in de Kolonie" tot gevangenisstraf voor de tijd van drie maanden en de kosten van het geding ad f. 4,60. De Gouverneur verleende op de dag van de uitspraak uit eigen beweging gratie aan de veroordeelde. 1)

Bij vonnis van 11 April 1928 werd de hoofdredacteur en uitgever van het Koloniaal Nieuws- en Advertentieblad Suriname veroordeeld tot hechtenis voor de tijd van zes weken wegens: ,,het uitgeven van een geschrift van strafbaren aard, zijnde de dader noch bekend, noch op de eerste aanmaning na den rechtsingang bekend gemaakt". Deze redacteur had in een artikel, „Uitstooten”, waarin de benoeming van een buiten de ambtenaarswereld staande persoon tot Districts-Commissaris fel werd gecritiseerd, onder meer geschreven ,,dat in Suriname in de laatste jaren door het Koloniaal Bestuur slechts uiting wordt gegeven aan persoonlijke antipathie of sympathie of ook om gevolg te geven aan wenschen en grillen van hotelvrienden, dischen gelaggenooten, of te wel pluimstrijkers, en voorts dat op geneeskundigen bedektelijk pressie werd geoefend tot het geestelijk en lichamelijk ongeschikt verklaren van staatskerk- en landsdienaren en waar het doel niet kon worden bereikt men de toevlucht tot machtsmisbruik nam".

Het Hof was van oordeel dat de passages in dit artikel een aantasting zijn van de zedelijke waarde en alzo beledigend voor

1) De voorgeschiedenis van dit delict is in brochurevorm uitgegeven onder de titel Een blik op het huidig bestuursbeleid in Suriname (Paramaribo, 1913); het bevat overdrukken uit De West. 
degene aan wiens handen het Bestuur van Suriname door de Koningin is toevertrouwd. Het college besliste ten aanzien van de vraag wat onder de uitdrukkingen ,,Koloniaal Bestuur” en ,, het Bestuur” moet worden verstaan: „, dat tenzij op dubbelzinnige wijze met die woorden degene die zich daarvan bedient, op een bepaald bestuursorgaan het oog heeft, aangenomen moet worden dat met deze uitdrukkingen gedoeld wordt op de bewindvoerende Gouverneur in wiens persoon ingevolge art. 29 van het Regeeringsreglement het bestuur over Suriname is belichaamd". Ten aanzien van de op te leggen straf werd overwogen dat deze straf een vrijheidsstraf behoort te zijn, zowel op grond van het ernstig karakter der beledigende passages van het onderwerpelijke artikel, als op grond van het feit dat in het door beklaagde in kalme gemoedstoestand en met volle wetenschap van de inhoud daarvan uitgegeven geschrift, de hoogste drager van het gezag in Suriname was beledigd ${ }^{1}$ ).

Dezelfde redacteur werd bij vonnis van 13 Juni 1929 door de Rechter-plaatsvervanger bij het Kantongerecht van Paramaribo veroordeeld tot een geldboete van f. 100 subsidiair 14 dagen hechtenis. Beklaagde had in zijn blad van 1 Febr. 1929 onder het hoofd „Rechtswezen” een artikel over de Surinaamse Justitie geschreven, waarin hij de afkeuring voor de verdere dienst in de tropen van de President van het Hof van Justitie mr S. D. DE VRIES ter sprake bracht en in verband daarmede geschreven dat hij hoopte dat de Gouverneur het daarheen zou leiden dat in elk opzicht onze rechtspleging een reorganisatie ondergaat en rechtschapen en hoogstaande Nederlandse rechtsgeleerden naar de kolonie worden gedetacheerd en een dergelijke maatregel tot gevolg zal hebben dat het zoek geraakte volksvertrouwen in de onkreukbaarheid van onze justitie gaandeweg zal worden herwonnen.

Bij de oplegging van de boete hield de Rechter rekening met het feit dat beklaagde de leeftijd van 60 jaar had overschreden.

Het volgend persdelict ging tegen de redacteur-uitgever van Jong Suriname, die de adjudant van de Gouverneur beledigde door in dit blad van 8 Dec. 1933, dat onder zijn aansprakelijkheid

1) In een brochure vatte de veroordeelde alle stukken in zake vervolging en veroordeling in de zaken samen, de stukken, het requisitor, pleidooi van de verdediger zijn daarin opgenomen; het vonnis van het Hof is voorzien van vele hatelijke aantekeningen. Aan de brochure is een aanhangsel toegevoegd, waarin het proces tegen de redacteur van De West in 1913 is weergegeven. 
werd uitgegeven, van deze adjudant te schrijven: ,,Wat verbeeldt dit gedropen soldaatje (een heele soldaat is hij in Holland nooit geweest) van zichzelf in Suriname. Ben je in de West ineens zoo'n fijne en gewichtige Hollander geworden?"'

Hij werd bij vonnis van 31 Jan. 1934 door de Kantonrechter van Paramaribo tot een geldboete van f. 40 subsidiair 14 dagen hechtenis veroordeeld.

Het jaar 1933 was een woelig jaar voor Suriname. Op 7 Febr. 1933 werd op last van de politie gevuurd op een opdringende volksmenigte tengevolge waarvan twee personen, die in de voorste gelederen stonden, de dood vonden. Dit feit veroorzaakte een grote opgewondenheid in de stad en de pers.

In het nieuwsblad De Banier van Waarheid en Recht verschenen over deze gebeurtenis verschillende opgewonden mededelingen en commentaren. O.m. werd, naar aanleiding van een wel zeer merkwaardige opgave in het officieel orgaan, Gouvernements Advertentieblad, van 24 Maart 1933, waarin te lezen stond dat in Februari twee personen waren overleden wegens ,,Moord door vuurwapenen", gezegd, dat officieel is vastgelegd dat deze twee mensen vermoord zijn en een strafactie niet mocht worden nagelaten.

In verband met een lezing die de Procureur-Generaal mr dr F. L. J. van HAREN voor de Vereeniging voor Dierenbescherming hield werd onder de rubriek ,Wist U” opgenomen: ,dat een menschen-moordenaar ook weleens dierenbescherming kan propageren".

De Procureur-Generaal achtte zich in hoge mate beledigd en in zijn eer en goede naam aangetast door deze artikelen die naar zijn mening inhielden dat hij, als hoofd van de gewapende politie, onnodig en tegen beter weten in het zou hebben aangelegd om op een weerloze volksmenigte te doen schieten en diende een klacht tegen de redacteur in.

Bij vonnis van het Hof van Justitie uitgesproken op 4 April 1934 werd de redacteur van De Banier van Waarheid en Recht schuldig verklaard aan: 1. smaadschrift aangedaan aan een ambtenaar ter zake van rechtmatige uitoefening zijner bediening, drie malen gepleegd; 2 . eenvoudige belediging, aangedaan aan een ambtenaar ter zake van de rechtmatige uitoefening zijner bediening, gepleegd als voortgezette handeling, en tot gevangenisstraf voor de tijd van vier weken veroordeeld

Als verweer tegen het artikel omtrent de mensenmoordenaardierenbeschermer voerde beklaagde aan dat hij daarmede HrT- 
LER had bedoeld, die een groot dierenvriend en dierenbeschermer is, terwijl beklaagde hem als een geweldenaar of moordenaar beschouwt om zijn Joden- en Negervervolgingen. Het Hof sloeg geen acht op dit verweer.

Dezelfde redacteur werd op 8 Dec. 1934 bij verstek veroordeeld wegens het overnemen van een artikel uit de Nederlandse pers, „Nieuwe Terreur in Suriname”, dat het Hof beledigend achtte voor de Procureur-Generaal.

Het verstekvonnis waarbij beklaagde tot vier weken gevangenisstraf werd veroordeeld werd na het verzet van de veroordeelde gewijzigd in een geldboete van f 100 subsidiair vier weken gevangenisstraf 1 ).

Daarna was het de beurt van het orgaan van de R.K. missie, De Surinamer.

In 1935 verscheen in dat blad onder de rubriek ,,Wereldnieuws" een artikel van de leken-redacteur, waarin de volgende zinsnede voorkwam: „De Führer blijkt dan al te vaak of wel weinig te zeggen te hebben als het er op aankomt of wel - wat erger is dubbelhartigheid van de lafste soort aan den dag te leggen en zich te verschuilen achter ondergeschikten".

Het Duitse consulaat vestigde de aandacht van het Parket op dit artikel en de redacteur werd vervolgd wegens belediging van Adolf Hitler, Hoofd van het Duitse Rijk.

Als verweer voerde hij aan dat hij niet het hoofd van het Duitse Rijk heeft gecritiseerd, maar alleen de Führer, als leider van de Duitse Nationaal Socialistische Partij. Dit verweer verwierp het Hof van Justitie bij vonnis van 27 Maart 1935 in uitgebreide overwegingen waarin het college tot de conclusie kwam dat een belediging van de „Führer” nadat deze Hoofd van het Duitse Rijk is geworden, als een belediging van een Staatshoofd moet worden aangemerkt.

Beklaagde werd veroordeeld wegens „opzettelijke beleediging een Hoofd van een bevrienden staat aangedaan" tot een geldboete van f. 25 of vervangende hechtenis voor de duur van een week. Ter motivering van de strafmaat overwoog het College dat het Hof rekening houdt met de omstandigheid dat beklaagde, die reeds vele jaren in de journalistiek werkzaam is, tevoren nog niet is veroordeeld en het Hof, niettegenstaande de ernst van

1) De veroordelingen van deze redacteur werden in de vergadering van de Tweede Kamer der Statengeneraal van 22 Febr. 1935 door verscheidene Kamerleden en de Minister van Koloniën besproken. 
het feit, ditmaal met een lichte bestraffing meent te kunnen volstaan.

Ruim twee jaren later werd de redacteur van De West vervolgd omdat hij het Gouvernement beticht had van het opzettelijk, willekeurig, tegen beter weten in krenken van het rechtsgevoel van derden. In dit blad verscheen nl. op 12 Maart 1937 een artikel handelende over het geval van zekere Schultz te Albina, wiens zes-riems vissersboot was ,gekapt” door gestraften, werkzaam onder militaire politiebeambten; het hout was als brandhout voor de gevangenis gebruikt. Schultz kon, hoewel hij hemel en aarde bewoog, geen vergoeding krijgen voor de aangerichte schade, en de redacteur van De West pleitte tevergeefs voor de eigenaar van de boot. In een artikel schreef deze redacteur: ,Maar wij kunnen ons de gemoedsgesteldheid indenken van iemand, wiens rechtsgevoel zoo lang en op zoo brutale wijze door het Gouvernement is verkracht".

De Kantonrechter in het Tweede Kanton veroordeelde beklaagd conform de eis van het O.M. bij vonnis van 13 Mei 1937 tot een geldboete van f. 25 subsidiair 5 dagen hechtenis ${ }^{1}$ ). De Kantonrechter overwoog dat het opzet om te beledigen alleen behoeft te worden gericht op de beledigende vorm, d.w.z. dat degene die de uitlating doet moet begrijpen, dus weten dat de vorm van de uitlating beledigend is.

$\mathrm{Na}$ zijn veroordeling schreef de redacteur een artikel, waarin hij de juistheid van het vonnis betwistte.

Het volgend persdelict ging weer tegen de redactie van $D e$ West, nu evenwel tegen een waarnemend redacteur, die een reeks van artikelen schreef over wantoestanden in 's Landshospitaal, meer in het bijzonder tegen de Chef, Cool. In een der artikelen schreef hij: ,Wat het lichtende Radium voegde aan den goeden naam van het Hospitaal werd de inrichting ontnomen door de bedorven Kool".

Beklaagde werd bij vonnis van 31 October 1938 ter zake van het zich in het openbaar bij geschrifte opzettelijk in beledigende vorm uitlaten over een in Suriname gestelde macht,veroordeeld tot een geldboete van f. 40 subsidiair 14 dagen hechtenis ${ }^{2}$ ).

1) In deze zaak trad de P. G. voor de eerste maal op als O.M. bij de Kantongerechten; door een wijziging van het Wetboek van Strafvordering bij K. B. van 19 Febr. 1937 (G. B. No. 22) was de mogelijkheid van dit optreden geschapen.

$\left.{ }^{2}\right)$ Als vrolijke noot aan deze veroordeling vertelde de veroordeelde in zijn blad het volgende: ,Beklaagde die planter was en zeer geinte- 
Het volgende persdelict uit meer recente tijd is niet het minst onvermakelijke.

In 1942 gaf de vereniging Suriname Waakt 1), een maandblad uit, met het doel Suriname in breder kringen bekend te maken en de meest gunstige indruk van dit land te vestigen. Een der redacteuren, een districts-commissaris, die tevoren bij het binnenlands bestuur in Indonesië had gediend, schreef artikelen, die de aandacht trokken vanwege hun frisse en originele stijl.

In het $8 \mathrm{e}$ nummer van het maandblad, in Nov. 1942 verschenen, schreef hij onder het hoofd „Om het heil van Groot-Nederland" een artikel gericht tegen de Surinaamse Volksvertegenwoordiging. O.m. werd van het College gezegd: ,Wij bekennen gaarne de lectuur van het Voorloopig Verslag der Commissie van Rapporteurs met betrekking tot de Surinaamsche Ontwerpbegrooting 1943 min of meer aemachtig te hebben beeindigd.” „Daarna overviel ons de onweerstaanbare behoefte de handen uitvoerig met zeepsop te behandelen..... Voor iemand met zelf-respect moet het een hard gelag zijn geweest dááronder zijn naam te plaatsen.... Zelden hebben wij een hoog openbaar college met zooveel vrijmoedigheid zich zelf een testimonium paupertatis zien uitreiken als in het onderhavig geval is gebeurd. Geestelijke onmacht tracht zich te verbergen achter een stroom van achterklap, vitterij, verdachtmaking en agitatie..... Goddank, dat democratie zooiets als een geloof is. In haar naam kan veel gezondigd worden. In haar naam kunnen wij veel verdragen. Maar daarom verdragen wij niet alles. Wij verdragen niet dat een harer hoogste goederen, de in strafrechtelijke zin gewaarborgde parlementaire immuniteit, wordt misbruikt om professionele malcontenten en pseudo-erudieten met een rudimentair verantwoordelijkheidsbesef in de gelegenheid te stellen een rol te spelen op kosten eener goedgeloovige massa".

resseerd in de koffieprijzen, ontmoette, komende van de zitting waarin zijn veroordeling was uitgesproken een collega-planter en vermoedende dat de uitspraak hem zou interesseren, riep hij hem toe: ,, ampat poeloe", hetgeen in het Maleis ,,veertig" betekent. De planter meende echter dat de koffieprijs tot veertig cent gestegen was en verspreide dit nieuws door de stad."

1) In de lijst van Surinaamse periodieken, in het werk van HaRTog, is dit blad niet opgenomen. - Het eerste nummer van Suriname Waakt verscheen in April 1942. Commissie van redactie: A. J. Morpurgo, dr J. W. Del Prado, J. E. Hagen, dr J. F. E. Einaar, J. D. Oppenheim en ir J. DE Kraker. Drukkerij: Eben Haezer. Het laatste nummer (No. 8) verscheen in Nov. 1942. 
Bij vonnis van 1 Febr. 1943 werd de schrijver door de Kantonrechter in het Tweede Kanton veroordeeld tot een geldboete van f. 75 subsidiair twee weken hechtenis wegens ,, het zich in het openbaar bij geschrift opzettelijk in beleedigenden vorm uitlaten over eene in Suriname gevestigd openbaar lichaam."

Het verweer van beklaagde dat het niet in zijn bedoeling lag om zich in beledigende vorm uit te laten werd verworpen. De Rechter overwoog dat beklaagde moest begrijpen dat de door hem in meerdere of mindere mate gebezigde nodeloos grievende, krenkende woorden en uitdrukkingen, waarvan hij geacht moest worden de portée ten volle te beseffen, aan de in de dagvaarding omschreven passages een beledigende vorm gaven.

Typisch voor de Surinaamse samenleving is dat het nummer waarin het artikel verscheen het laatste van het tijdschrift was; geen der redacteuren durfde blijkbaar de uitgave voortzetten.

Het duurde tot 1950 vóór er weer persdelicten te vermelden zijn.

De redacteur van Het Nieuws werd op 3 April 1950 door de Kantonrechter in het Tweede Kanton wegens belediging van de Staten veroordeeld tot een boete van f. 50 of één week hechtenis. In zijn blad schreef hij, doelende op de Staten, over ,,politiek gesproken onrijpe kwajongens”. In hoger beroep sprak het Hof van Justitie hem op 19 Juli 1950 vrij, uit overweging dat niet is bewezen dat beklaagde het college der Staten heeft beledigd, doch het geschrevene gericht is tegen de algemene houding van enige Statenleden in de vergadering van 23 Januari 1950.

De politieke verhoudingen waren oorzaak dat het aantal persdelicten toenam. De redacteur van De West stond in een eerste aanleg wegens smaadschrift en belediging terecht. Aangezien het tegen dit vonnis aangetekend hoger beroep nog niet behandeld is, volstaan wij met slechts de vermelding van het feit. Het tegen hem gewezen vonnis werd in de pers becritiseerd en naar aanleiding van deze critiek werd op 11 December 1950 de ex hoofdredacteur van Reveille veroordeeld tot een boete van f. 75 en een voorwaardelijke gevangenisstraf van veertien dagen. Tot zover mij bekend, is tegen dit vonnis geen beroep aangetekend. Ons overzicht is bijgewerkt tot eind 1950. Enkele zaken zullen nog worden berecht; zolang echter de politieke rust in Suriname niet is teruggekeerd is helaas te vrezen, dat vervolgingen zullen worden ingesteld. 
In vorenstaande opsomming hebben wij slechts die persdelicten opgenomen die tot een veroordeling hebben geleid.

Als een merkwaardigheid willen wij nog vermelden een poging van een redacteur van een plaatselijk blad om een veroordeling tegen collega's uit te lokken.

In het jaar 1925 diende de redacteur van De West een strafklacht in tegen twee redactieleden van Suriname wegens belediging ter zake van het schrijven van het artikel ,Schijnheiligheid". Het Hof weigerde bij beschikking van 5 Maart 1926 de rechtsingang en stelde de redacteuren buiten vervolging op grond van de overweging dat niet gebleken is dat de kennelijke strekking van het artikel is om de klager als een omkoopbaar journalist aan de kaak te stellen en de inhoud ook overigens niet gebleken is van beledigende aard te zijn in de zin van het Wetboek van Strafrecht, al zij het dan ook dat de heftige toon waarin bedoeld artikel gesteld is niet aan de eisen van guede journalistiek beantwoordt.

\section{S UMMAR Y}

In this article are enumerated the legal actions brought in the course of a couple of centuries against newspaper editors in Suriname, on account of misdemeanours committed by them in their publications.

Although in 1796 already we find a complaint against the Surinaamsche Spectator, it was the violent criticism started about 1870 of the governmental policy which gave cause to the majority of the prosecutions related by the author of the above article. The first of the actions of this class is the one of Febr. 25th 1871.

The intensification of the political opposition in more recent times is responsible for the increase of criminal proceedings against newspapers in Suriname, shown in this article. 